DOI: 10.46340/eujem.2020.6.4.5

\author{
Anna Gramatik \\ ORCID ID: https://orcid.org/0000-0001-6153-5664 \\ Olena Bilous \\ ORCID ID: https://orcid.org/0000-0002-5130-1781 \\ Institute of Market Problems and Economic and Ecological Research of NAS of \\ Ukraine
}

\title{
SCIENTIFIC SUPPORT FOR CLUSTERIZATION \\ PROCESSES IN THE CONTEXT OF INNOVATIVE DEVELOPMENT OF REGIONS
}

\author{
Ганна Граматік \\ Олена Білоус \\ Інститут проблем ринку та економіко-екологічних досліджень НАН України
}

\section{НАУКОВЕ ЗАБЕЗПЕЧЕННЯ ПРОЦЕСІВ КЛАСТЕРИЗАЦІЇ В КОНТЕКСТІ ІННОВАЦІЙНОГО РОЗВИТКУ РЕГІОНІВ}

The article deals with the formation of cross-border clusters as a factor of the innovative development of regions and scientific support for these processes. The authors define the economic essence of the concept of "cluster", consider the role of cluster formations in increasing the competitiveness of the region and intensifying its innovative development. The classification of cluster types is carried out and the peculiarities of cross-border cluster formation are highlighted. The specifics of the formation of agro-ecological clusters are considered and the role of scientific expertise in strengthening clustering processes is analyzed, in particular, in the agrarian sphere (on the example of the cross-border agro-ecological cluster "Frumushika-Nova"). Scientific provisions, obtained results and proposed recommendations are a practical basis for the development and improvement of the clustering process in Ukraine.

Keywords: cluster, competitiveness, cross-border cluster, agro-ecological cluster, innovative development, region, economy clustering, scientific expertise.

Постановка проблеми у загальному вигляді. Розвиток сучасної економіки в умовах глобалізації, постіндустріального суспільства та інформатизації характеризується тенденцією посилення конкуренції регіонів та окремих територій. Характерні для останніх років широкомасштабні трансформації в економіці, інтеграційні процеси, перехід до нової схеми державного устрою, що припускає зміну адміністративних і бюджетних відносин центру і регіону, призвели до формування низки негативних тенденцій в розвитку регіональних систем, що свідчить про зниження ефективності традиційних адміністративних та інституційних механізмів державного регулювання регіонального розвитку. Визначальним чинником їх подолання та посилення рівня конкурентоспроможності національної економіки на інноваційній основі стає кластеризація, як основа ефективного використання та створення регіональних ресурсів для підвищення конкурентного статусу в геоекономічному просторі на основі поширення кластерів ${ }^{1}$. Особлива роль у цих процесах належить транскордонним кластерам як новій формі транскордонного співробітництва та інноваційного інструменту державної регіональної політики в Україні; що має забезпечити сталий розвиток та конкурентоспроможність українських прикордонних регіонів та сприятиме інтеграції України у світовий економічний.

\footnotetext{
${ }^{1}$ Гончарова, К. В. (2009) Вдосконалення методики визначення потенціалу кластеризації галузей окремого регіону. Економічний простір, 29, 80-89.
} 
Аналіз останніх досліджень і публікацій. Дослідження питань створення та функціонування кластерів та їх ролі узабезпечення інноваційного розвитку регіонів здійснюється такими зарубіжними та вітчизняними теоретиками як Портер М., Коуз Р., Войнаренко М.П., Захарченко В.I., Осипов В.М., Макаренко М.В., Назаренко С.А. та ін.

Питання регіональної політики, транскордонного співробітництва, створення та розвитку єврорегіонів, формування транскордонних кластерів висвітлюються у працях таких українських вчених Долішнього М.І., Федулової Л.І., Мікули Н.А., Мокія А.І., Студеннікова І.В. та ін.

Як елемент інноваційного спрямування, створення кластерів спостерігається в багатьох секторах економіки держави та регіонів.

Чужиков B.I. розглядає поняття кластера як конкурентоспроможну організаційну форму територіально-ієрархічної моделі виробництва з різними рівнями локалізації, яка дає максимальний господарсько-соціальний ефект через мінімізацію видатків у порівняно подібних галузях, та в основі кластерної системи передбачає таку передумову як концентрація ${ }^{1}$.

Саблук П.Т. зазначає: «...кластерні системи є втіленням комбінації наукових, виробничих і комерційних структур, i на основі використання переваг коопераційної взаємодії сприяють формуванню і ефективному використанню реальних конкурентних переваг окремих підприємств, галузей, регіонів, національних економік в умовах посилення світового конкурентного протистояння. На даному етапі розвитку економіки України кластери можуть виступити ефективним інструментом інтенсифікації розвитку вітчизняного підприємництва і посилення ринкових позицій окремих економічних суб'єктів»².

Войнаренко М.П. трактує поняття «кластер» як територіально-галузеве добровільне об’єднання підприємств, що тісно співпрацюють з науковими установами та органами місцевої влади 3 метою підвищення конкурентоспроможності власної продукції й економічного зростання регіону 3 .

За теорією М. Портера, «кластер - це група географічно сусідніх взаємопов'язаних компаній i пов'язаних з ними організацій, що діють в окремій сфері і характеризуються спільністю діяльності і взаємодоповнюючих один одного» ${ }^{4}$.

Виділення невирішених раніше частин загальної проблеми. Не дивлячись на велику кількість досліджень 3 проблем кластеризації національної та регіональної економіки, залишається низка невирішених питань щодо шляхів розвитку та ефективного функціонування транскордонних кластерів на території України, а також наукового забезпечення даних процесів.

Метою дослідження $є$ обгрунтування теоретико-методичних засад та розробка практичних рекомендацій щодо розвитку процесів кластеризації в Україні як чинника інноваційного розвитку регіонів, в аспекті створення транскордонних кластерів, а також наукового забезпечення даних процесів.

Реалізація поставленої мети зумовила розв'язання наступних завдань:

- визначити економічну сутність понять «кластер» та встановити роль кластерних утворень у підвищенні конкурентоспроможності регіону та активізації його інноваційного розвитку;

- класифікувати види кластерів та розглянути особливості формування транскордонних кластерів;

- розглянути специфіку формування агро- та агроекологічних кластерів;

- проаналізувати роль наукової експертизи в посиленні процесів кластеризації, зокрема у аграрній сфері (на прикладі транскордонного агро-екологічного кластеру «Фрумушика-Нова»).

Виклад основного матеріалу. Кластерам належить провідна роль у відродженні національної економіки. При дослідженні економічної природи кластерів як зарубіжні так і вітчизняні вчені акцентують увагу на ролі процесів кластеризації у забезпеченні конкурентоспроможності регіону.

Згідно 3 кластерною політикою Портера, підвищення конкурентоспроможності регіону відбувається за трьома основними напрямками: підвищення продуктивності компаній, які працюють у їх бізнесі, підвищення рівня інновацій і стимулювання формування нових компаній. Характерною особливістю кластерів є те, що компанії, зосереджені на даній території, конкурують одна з одною, але у той самий час співпрацюють у тих сферах, де можна випустити ефект синергії спільних дій

\footnotetext{
1 Якель, Р. (2010) Знання плюс...кластеризація економіки. Дзеркало тижня, 17, 30 квітня.

${ }^{2}$ Саблук, П. Т. (2010) Кластеризація як механізм підвищення конкурентоспроможності та соціальної спрямованості аграрної економіки. Економіка АПК, 1, 3-12.

${ }^{3}$ Войнаренко, М. (2014) Кластери в економіці України. Хмельницький: ХНУ, ФОП Мельник А. А.

${ }^{4}$ Портер, М. (2000) Конкуренщия. Москва: Вильямс.
} 
(наприклад, спільні дослідження та розробки). Конкуренція не виключає взаємодії з іншими компаніями i може стати рушійною силою іх розвитку. Це явище називається в управлінні «Coopetition» (що з англ. означає комбінацію слів співпраця і конкуренція). Це так би мовити, співробітництво між бізнес-конкурентами з взаємовигідними результатами. Така ситуація можлива тоді, коли існує питома концентрація у цьому секторі ресурсів і досвіду для досягнення критичної маси, за якої кластер стає привабливим центром і місцем залучення додаткових ресурсів.

Прикладом цього ефекту є Силіконова долина у США (Каліфорнія), у яких розвиток індустрії інформаційних технологій привернув і продовжує залучати кращих комп'ютерних учених з усього світу, що дає можливість підприємствам, розташованим у ній, збільшувати свої переваги над конкурентами.

Враховуючи те, що кластери мають широкий діапазон діяльності, існує необхідність класифікувати їх за територіальним розподілом праці. Так, вирізняють регіональні, міжрегіональні та міжнародні, зокрема, транскордонні кластери. Регіональні кластери створюються у межах одного регіону та орієнтовані на певну географічну концепцію взаємопов'язаних галузей. Міжрегіональні включають підприємства, організації та установи, розташовані у різних областях країни, і вони першочергово орієнтуються на зовнішній ринок, тобто на експорт, і ставлять собі за мету створити конкурентоспроможну продукцію. Міжнародні, зокрема, транскордонні кластери здійснюють свою діяльність у межах двох або більше країн ${ }^{1}$.

Транскордонні кластериє новою формою транскордонного співробітництва у сучасних умовах розвитку транскордонної співпраці між сусідніми державами.

Транскордонний кластер є формою інтеграції незалежних компаній та асоційованих інституцій, що географічно зосереджені у транскордонному регіоні, спеціалізуються у різних галузях, пов'язані спільними технологіями та навичками і взаємодоповнюють одна одну, яка грунтується на наявності погодженої стратегії розвитку учасників кластера ${ }^{2}$.

Пропонується таке трактування поняття транскордонний кластер: це модель кластерної організації, яка передбачає локалізацію взаємопов'язаних підприємств та інституцій на транскордонній території, дає змогу реалізувати якнайкращий взаємозв'язок виробництва, науково-технологічного потенціалу, маркетингу, попиту споживачів та визначає спрямованість і темпи інновацій з метою підвищення конкурентоспроможності кінцевої продукції та ефективності виробництва загалом як для внутрішнього, так і для зовнішнього ринків.

Особливістю транскордонних кластерів $є$ те, що їх учасники розташовані у різних податкових, митних, законодавчих середовищах сусідніх країн, однак можуть мати спільні підприємства та організації, користуватися спільною інфраструктурою і функціонують на транскордонних ринках. Ще однією особливістю $є$ те, що інтенсивність мережевих взаємодій у транскордонному кластері обмежується наявністю кордону, який створює додаткові бар'єри для вільного руху товарів, робочої сили, капіталу. Бар'єрами для налагодження співпраці також можуть бути різний менталітет, традиції, мова, культура, негативні сторінки історії тощо ${ }^{3}$.

Слід зазначити, що транскордонне співробітництво направлено не тільки на задоволення потреб внутрішнього ринку, а і дає можливість використовувати зовнішньо-економічні канали зі збуту своєї продукції та послуг. Це дозволяє вийти на європейські ринки та отримати більш значний ефект від функціонування транскордонного кластеру.

Така форма транскордонного співробітництва, як транскордонні кластери, поширена у провідних країнах світу та країнах, що розвиваються, проте найпоширенішою вона $\epsilon$ на європейських кордонах, де основна мета транскордонного кластера - прискорити економічне зростання шляхом об'єднання зусиль учасників, забезпечення конкурентних переваг транскордонним регіонам.

У випадку сільськогосподарської діяльності та пов'язаної з нею переробною промисловістю і суміжними секторами (технічна підтримка, сервіс, ринки та біржі тощо) формуються агрокластери підприємницькі угрупування, що взаємодіють усфері аграрного виробництва та формують

\footnotetext{
${ }^{1}$ Мікула, Н. А. (2011) Сучасні підходи до визначення сутності та класифікації кластерів. Наукові записки, 1, 71-77.

2 Добрєва, Н. (2013) Основні напрями розвитку транскордонних кластерів в Україні. Ефективність державного управління, 34, 246-253.

${ }^{3}$ Мікула, Н. А. (2011) Транскордонне співробітництво: посібник. Київ: Крамар.
} 
відповідний ланцюжок доданої вартості, задля максимального виявлення, формування та використання своїх конкурентних переваг ${ }^{1}$.

Кластерний підхід для агросектору і розвитку сільських територій України стає актуальним в умовах, коли основну масу виробників у сільських громадах складають дрібні і середні підприємці, фермери та особисті селянські господарства, яким складно конкурувати з великими агрохолдингами. І саме інтеграція дрібних сільгоспвиробників дозволяє в умовах спільної координації, вироблення єдиної виробничо-комерційної політики посилювати їхні конкурентні переваги, знаходити свої ніші і бути успішними.

Специфіка агроекологічних кластерів пов'язана з особливостями та умовами діяльності суб'єктів господарювання на сільських територіях - експлуатацією (природокористуванням) первинних природних ресурсів (грунти, вода, ліси, біоресурси тощо), та залежність від природних умов (клімат та його зміна, погода) та ресурсів (земля, вода тощо) ${ }^{2}$.

Важлива роль у успішному формуванні та функціонуванні регіональних кластерів належить науковому забезпеченню. Науковий сектор - наукові установи, університети, наукові та інноваційні центри, підвищують конкурентоспроможність своїх громад та регіонів шляхом здійснення фундаментальних та прикладних досліджень, генерування неявних і кодифікованих знань, розвитку висококваліфікованих кадрів . Завдяки активній інституційній взаємодії з університетами та науковими установами місцеві партнери та стейкхолдери отримують доступ до нових ідей та свіжих поглядів на актуальні та складні проблеми через різноманітні механізми трансферу знань, включаючи консультації та наукову експертизу, спільні дослідницькі проекти, наймання випускників, що здійснюють наукові дослідження та розробки . Залученість наукових організацій у місцевий економічний розвиток $є$ критично важливою для стимулювання формування кластерів, особливо в галузях, що базуються на знаннях.

Розглянемо роль наукового забезпечення процесів агроекологічної кластеризації Одеської області.

Ініціатива щодо застосування агроекологічних кластерів в якості інструменту розвитку сільських територій належить Міністерству аграрної політики та продовольства України. У січні 2017 року були оголошені шість пілотних агроекологічних кластерів, у тому числі «ФрумушикаНова» в Одеській області . 3 цього часу при координації Одеської обласної державної адміністрації та із залученням наукових кіл регіону (представників ЗВО та наукових установ), місцевих органів влади Тарутинського району та представників кластеру «Фрумушика-Нова» було проведено дослідження потенціалу розвитку агроекологічного кластеру «Фрумушика-Нова». Так науковоекспертною групою проекту «Пілотне впровадження дій зі створення агроекологічних кластерів для сталого розвитку в Одеській області» на основі узагальнення практичного досвіду зі створення агроекологічних кластерів на Одещині, починаючи з 2017 року, було проведено дослідження та здійснено комплексну оцінку передумов та можливостей для агроекологічної кластеризації в Одеській області, зокрема було визначено локації у сільській місцевості з високим потенціалом для створення агроекологічних кластерів. Як результат, на Одещині започатковані два агро-екологічних кластери різного спрямування - агро-еколого-рекреаційний кластер «Фрумушика-Нова» та медовогоріховий «Агропромисловий кластер Причорномор'я».

Проект «Фрумушика-Нова» бере свій початок ще в 2006 році, коли почалося його будівництво на місці молдовських сіл Фрумушика-Нова і Рошия, виселених навесні 1946 року узв'язку з утворенням військового полігону. Фрумушика-Нова розташовується на території Веселодолинської сільської ради Тарутинського району Одеської області.

Сьогодні це центр етнографічного, сільського зеленого туризму та сімейного відпочинку. На його території розташовується найбільший в Європі вівчарський комплекс по вирощуванню овець каракульської породи, найвищий гранітний пам'ятник України, внесений до Національного реєстру рекордів України, етнографічний музей просто неба, центр сімейного відпочинку, парк скульптур, міні-зоосад.

\footnotetext{
${ }^{1}$ Мельник, Ю. І., Дьяков, О. А. (2019). Практична настанова та методичні рекомендації зі створення агроекологічних кластерів для сталого розвитку сільських територій. Одеса: Центр регіональних досліджень. ${ }^{2}$ Мельник, Ю. І., Дьяков, О. А. (2019). Практична настанова та методичні рекомендації зі створення агроекологічних кластерів для сталого розвитку сільських територій. Одеса: Центр регіональних досліджень.
} 
Ідеологія формування транскордонного агро-екологічного кластера «Фрумушика-Нова» полягає в наступному:

- об'єднання економічних, соціальних, екологічних та інших інтересів для зміцнення економічного потенціалу і досягнення більш високих показників сталого розвитку;

- представництво і захист законних прав та інтересів, створення правових, організаційних, економічних, технічних умов для стабільного розвитку регіону;

- сприяння реалізації кластерних ініціатив в Тарутинському районі Одеської області, Україні, Молдові та Румунії;

- створення полюсів і точок економічного зростання на основі стратегічних пріоритетів та інвестиційної привабливості;

- підвищення рівня життя населення на проектній території.

Мета і етапи формування:

1) створення організаційної, наукової, технічної та прикладної платформи сталого розвитку громад Тарутинського району Одеської області, які розташовані в зоні депресивних степових ландшафтів;

2) впровадження принципів сталого розвитку територій і громад південних областей України;

3) формування моделі ефективного та екологічно прийнятного природокористування в степовій зоні; пошук та використання внутрішніх конкурентних переваг, залучення інвестицій, бюджетних коштів, міжнародної технічної допомоги;

4) сприяння розвитку підприємницьких структур і створення нових інноваційних утворень на проектній території;

5) пошук і реалізація інших напрямків і методів розвитку громад, територій, які сприятимуть підвищенню якості життя населення на проектній території.

В даний момент отримують розвиток такі структурні підрозділи, які входять до складу кластера:

- Субрегіональний кластер "Вівчарство";

- Секторальний кластер "Лаванда";

- Виноградно-виробничий кластер;

- Регіональний кластер "Рекреація і туризм".

Сьогодні «Фрумушика-Нова» працює як єдина система, стратегічний успіх якої був закладений ще на стадії формування ідеї і проектування. Цей досвід і напрацювання мають стати імпульсом для подальших процесів кластеризації.

Кластер знаходиться в стадії економічного зростання та посилює свої інноваційні, виробничі зв'язки з Молдовою та Румунією. В майбутньому планується участь у міжнародних грантових проектах та програмах розвитку, тим самим створюючи більш сприятливі умови для інклюзивного розвитку регіону.

Висновки. Оскільки агро-еколого-рекреаційний кластер «Фрумушика-Нова» став пілотним в Одеській області та одним з перших в Україні планів реалізації кластерних ініціатив, досвід його створення та використання надав суттєвий матеріал для дослідження і послугував платформою, на якій опрацьовуються методологічні підходи та здійснюється ідентифікація для інших потенційних локацій для кластерних утворень в регіоні.

Отриманий досвід дозволить сформувати загальне бачення щодо агроекологічної кластеризації сільських територій в контексті державної аграрної та регіональної політики, напрацювати методологічний інструментарій та підходи для створення агроекологічних кластерів у інших регіонах України, структурований порядок дій для ефективної реалізації концепції агроекологічних кластерів в Україні як ефективних інструментів стимулювання сталого розвитку сільських територій в умовах глобальних викликів.

Результатом дослідження також стало удосконалення методологічного інструментарію політики регіонального розвитку на рівні центральних та обласних органів влади 3 проекцією на місцевий рівень - сільські територіальні громади в умовах децентралізації в Україні.

\section{References:}

1. Honcharova, K. V. (2009). Vdoskonalennia metodyky vyznachennia potentsialu klasteryzatsii haluzei okremoho rehionu [Improving the methodology for determining the clustering potential of industries in a particular region]. Ekonomichnyi prostir [Economic space], 29, 80-89. [in Ukrainian]. 
2. Yakel, R. (2010). Znannia plius...klasteryzatsiia ekonomiky [Knowledge plus... clustering of the economy]. Dzerkalo tyzhnia [Mirror of the week], 17, April, 30. [in Ukrainian].

3. Sabluk, P. T. (2010). Klasteryzatsiia yak mekhanizm pidvyshchennia konkurentospromozhnosti ta sotsialnoi spriamovanosti ahrarnoi ekonomiky [Clustering as a mechanism for increasing the competitiveness and social orientation of the agricultural economy]. Ekonomika APK [Economics of agro-industrial complex], 1, 3-12. [in Ukrainian].

4. Voinarenko, M. (2014). Klastery v ekonomitsi Ukrainy: monohrafiia [Clusters in the economy of Ukraine: a monograph]. - Khmelnytskyi: KhNU, FOP Melnyk A.A. [in Ukrainian].

5. Porter, M. (2000). Konkurentsyia: uchebn. Posobie [Competition: textbook]. Moscow: Vyliams. [in Russian].

6. Mikula, N. A. (2011). Suchasni pidkhody do vyznachennia sutnosti ta klasyfikatsii klasteriv [Modern approaches to defining the essence and classification of clusters]. Naukovi zapysky [Scientific Notes], 1, 71-77. [in Ukrainian].

7. Dobrieva, N. (2013). Osnovni napriamy rozvytku transkordonnykh klasteriv v Ukraini [The main directions of development of cross-border clusters in Ukraine]. Efektyvnist derzhavnoho upravlinnia [Efficiency of Public Administration], 34, 246-253. [in Ukrainian].

8. Mikula, N. A. (2011). Transkordonne spivrobitnytstvo: posibnyk [Cross-border cooperation: a guide]. Kyiv: Kramar. [in Ukrainian].

9. Melnyk, Yu. I., Diakov, O. A. (2019). Praktychna nastanova ta metodychni rekomendatsii zi stvorennia ahroekolohichnykh klasteriv dlia staloho rozvytku silskykh terytorii [Practical guide and methodological recommendations on the creation of agro-ecological clusters for sustainable development]. Odesa: Tsentr rehionalnykh doslidzhen. [in Ukrainian].

10. Bramwell, A., Hepburn, N., Wolfe, D. (2012). Growing Innovation Ecosystems: University-Industry Knowledge Transfer and Regional Economic Development in Canada. Final Report to the Social Sciences and Humanities Research Council of Canada. [in English].

11. Klein, E., Woodell, J. (2015). Higher Education Engagement in Economic Development: Foundations for Strategy and Practice. Economic Engagement Framework. August 2015. Association of Public and Land-Grant Universities and University Economic Development Association. [in English].

12. Minahropolityky (2016) [Ministry of Agrarian Policy (2016]. U 2016 rotsi rozpochato stvorennia 6 ahrorekreatsiinykh klasteriv [In 2016, the creation of 6 agro-recreational clusters began]. Ofitsiinyi sait Kabinetu Ministriv Ukrainy [Official website of the Cabinet of Ministers of Ukraine] $<$ https://kmu.gov.ua/ua/news/249644829> (2020, July, 31). [in Ukrainian]. 